\title{
INTANGIBLE ASSETS AND THE ACCOUNTING REPRESENTATION CRISIS'
}

\author{
Eduardo José Zanoteli ${ }^{2}$ \\ Hudson Fernandes Amaral ${ }^{3}$ \\ Antônio Artur de Souza ${ }^{4}$
}

\begin{abstract}
This theoretical essay aims to promote a reflection on the accounting process' ability to capture and represent the companies' economical status through accounting statements. It puts in question the current model of recognition, measurement, and disclosure. This reflection particularly focuses on the intangible assets, which have been widely recognized as the most relevant assets in the current days, yet rarely stated and measured adequately in the accounting statements. This reduces the informational power and the usefulness of such statements. Assuming the likelihood that accounting has been going through a representational crisis, a crisis in which the intangible assets play a crucial role, this essay, consistent with critiques emerging in the financial and capital markets, recommends a wide re-examination of the philosophical and theoretical grounds of the current accounting model. This leads to an issue that seems to be inevitable: the accounting professionals will have to face the challenge of subjectivity and discretion, feared by some, desired by others, but fundamental to everyone. Without subjectivity and discretion, accounting will remain far-off from the company's economical representation.
\end{abstract}

Keywords: Intangible assets. Post-structuralism. Discretion. Representation crisis.

1 Ensaio apresentado no $13^{\circ}$ Congresso de Controladoria e Contabilidade da USP, 2013.

22 E-mail: edujz@hotmail.com - UFES - Universidade Federal do Espírito Santo.

${ }^{3} 3$ E-mail: hfamaral@face.ufmg.br - UFMG - Universidade Federal de Minas Gerais e UNILISBOA - Universidade de Lisboa.

${ }^{3} 4$ E-mail: artur@face.ufmg.br - UFMG - Universidade Federal de Minas Gerais. 


\section{OS ATIVOS INTANGÍVEIS E A CRISE DE REPRESENTAÇÃO CONTÁBIL}

Resumo: O objetivo deste ensaio teórico é provocar uma reflexão sobre a capacidade de o processo contábil capturar e representar a realidade econômica das empresas por meio das demonstrações contábeis, questionando assim o modelo atual de reconhecimento, mensuração e evidenciação. Destacam-se nessa reflexão, os ativos intangíveis, pois mesmo sendo amplamente reconhecidos como os ativos mais relevantes da atualidade, raramente encontram-se demonstrados e mensurados adequadamente nas demonstrações contábeis, reduzindo assim, o poder informacional e a utilidade dessas demonstrações. A partir da constatação da possibilidade de que a contabilidade esteja passando por uma crise de representação, da qual os ativos intangíveis ocupam lugar de destaque, recomendase uma ampla revisão das bases filosóficas e teóricas que conduziram a contabilidade ao modelo vigente, o qual vem sendo severamente questionado pelo mercado financeiro e de capitais. Para tanto, uma questão parece inevitável: os profissionais da contabilidade terão que enfrentar o desafio da subjetividade e da discricionariedade, temidas por uns, desejadas por outros, mas fundamental para todos, pois sem elas, a contabilidade continuará se distanciando da representação econômica das empresas.

Palavras-chave: Ativos intangíveis. Pós-estruturalismo. Discricionariedade. Crise de representação.

\section{INTRODUCTION}

A nglo-Saxon countries, such as the United States and England, started divulging intangible assets on accounting statements in the 1970s. Information about these assets are normally recognized part in Balance Sheets and part in Income Statements - for example, Research and Development (R\&D) expenses. However, the informational content of intangible assets has proved relevant to the Financial and Capital Market, as concluded Aboody and Lev (1998), Lev and Zarowin (1999).

In Brazil, Martins (1972) heralded the analysis of intangible assets, also presenting criteria for recognizing them. Nevertheless, it was only after 2006, three decades later, through the Comissão de Valores Mobiliários (CVM) deliberation 488/2005, that the process of divulging intangible assets separately on accounting statements has begun. To aid the consolidation of this process, the law 11.638/2007 has been published and pronouncements by the Comitê de Pronunciamentos Contábeis (CPC), which are aligned with international accounting standards, have been adopted. 
Until 2005, orientations of law 6404/1976 and of Brazilian tax laws prevailed, which allowed capitalizing part of intangible assets, registered sometimes under fixed assets, such as software use rights and brands and patents, sometimes under deferred asset, such as R\&D, or else, under expenses - the latter being the most common case. It is important to note that the informational content of intangible assets has been divulged among the fixed and deferred assets, in the results of the period, and sometimes through notes, that, besides misleading the accounting information users, compromised this information relevance, as demonstrated by Lopes and Rezende (2005), Alencar and Dalmácio (2006) and Almeida et al (2009), who used deferred assets as a proxy for intangible assets.

Moreover, the situation was even more complex when divulging intangible assets among deferred assets, for pre-operating and pre-production expenses, and other expenses also considered as deferred, all were accounted on this group, making the conceptual misleading between those asset items even worse, especially for intangible assets. At times, Brazilian tax laws determined that some values that were not related to the concept of "deferred" used in Brazil, and even less related with the concepts of "assets" and "intangible assets", should be registered under deferred assets values.

In this regard, many studies have demonstrated that accounting rules do not allow to recognize the total economic value of intangible assets - for example Amir and Lev (1996) and Hand and Lev (2003). Moreover, the consequences of shortcomings in recognizing, measuring and disclosing intangible assets have been thoroughly studied (Lev, Sougiannis, 1996 and Lev, Zarowin, 1999, Aboody and Lev, 1998 and Lev et al, 2005).

Damodaran (2007) highlights that traditional accounting rules either underestimate the intangible assets value or ignore them completely, and he also emphasizes that Balance Sheets show little evidence of its value. Thus, the International Accounting Standards Board (IASB), together with the Financial Accounting Standards Board (FASB), acknowledged in 2007 the possibility of reviewing the accounting standards related to intangible assets, acknowledging also that the International Accounting Standards (IAS) 38 does not address the issue adequately (Morricone et al, 2009).

It is within this context that we outline the orienting questions of this essay: Does the current accounting process of recognition, measurement and disclosure allow an adequate representation of companies' economic reality? Are intangible assets relevant for this representation?

\section{ACCOUNTING STATEMENTS AND THE FINANCIAL AND CAPITAL MARKET}

Following Hendriksen and Van Breda (1999), Watts and Zimmerman (1986), Palepu and Healy (2008), Scott (2012) and Lopes and Martins (2007), this essay considers accounting statements relevant to the decision-making process, especially to participants in the financial and capital market, since these statements may contribute to projecting future cash flows. However, it is possible to raise some questions: on which context could this premise be grounded? Why is this prerogative ascribed to accounting statements?

Palepu and Healy (2008) emphasize that financial and information intermediaries and are important to the financial and capital market, since they contribute to the communication process between investors and entrepreneurs, which helps entrepreneurs distinguish the good from the bad investment 
opportunities available (Papelu \& Healy, 2008). Thus, accounting plays an important role by providing "useful information for the decision-making process concerning companies and companies' investments and loans" (Hendriksen; Van Breda, 1999, p. 115). Nevertheless, for this contribution to be effective, it is necessary to make the Efficient Market Hypothesis (EMH), by Fama (1970), at least more flexible; because, if all the available information is equally accessible by all market participants, costlessly, the accounting statements adds little to no value to the financial and capital market.

In this regard, it is important to recognize, following Akerlof (1970), that the information flow between market participants is not perfect, leading to informational asymmetry, which is a direct argument against EMH and calls into question the "firm" idea in classical economics. It is in this market context, in which participants want to negotiate, need to communicate and do not have the same informational level, that accounting maximizes its utility, as it may serve as one of the main information sources for the market, contributing significantly to this "break" of informational asymmetry.

As Lopes and Martins (2007, p. 76) highlight, however, in order to achieve that, accounting statements should be closely related to the companies' economic reality, because "accounting utility relates to its ability to change the users' beliefs about assets' future cash flows". Nevertheless, to make this premise real is a serious challenge. Figure 1 illustrates the process of aggregate a company's economic activities into accounting statements.

Figure 1: From business activities to financial statements (Adapted from Palepu and Healy, 2008, p. I-4)

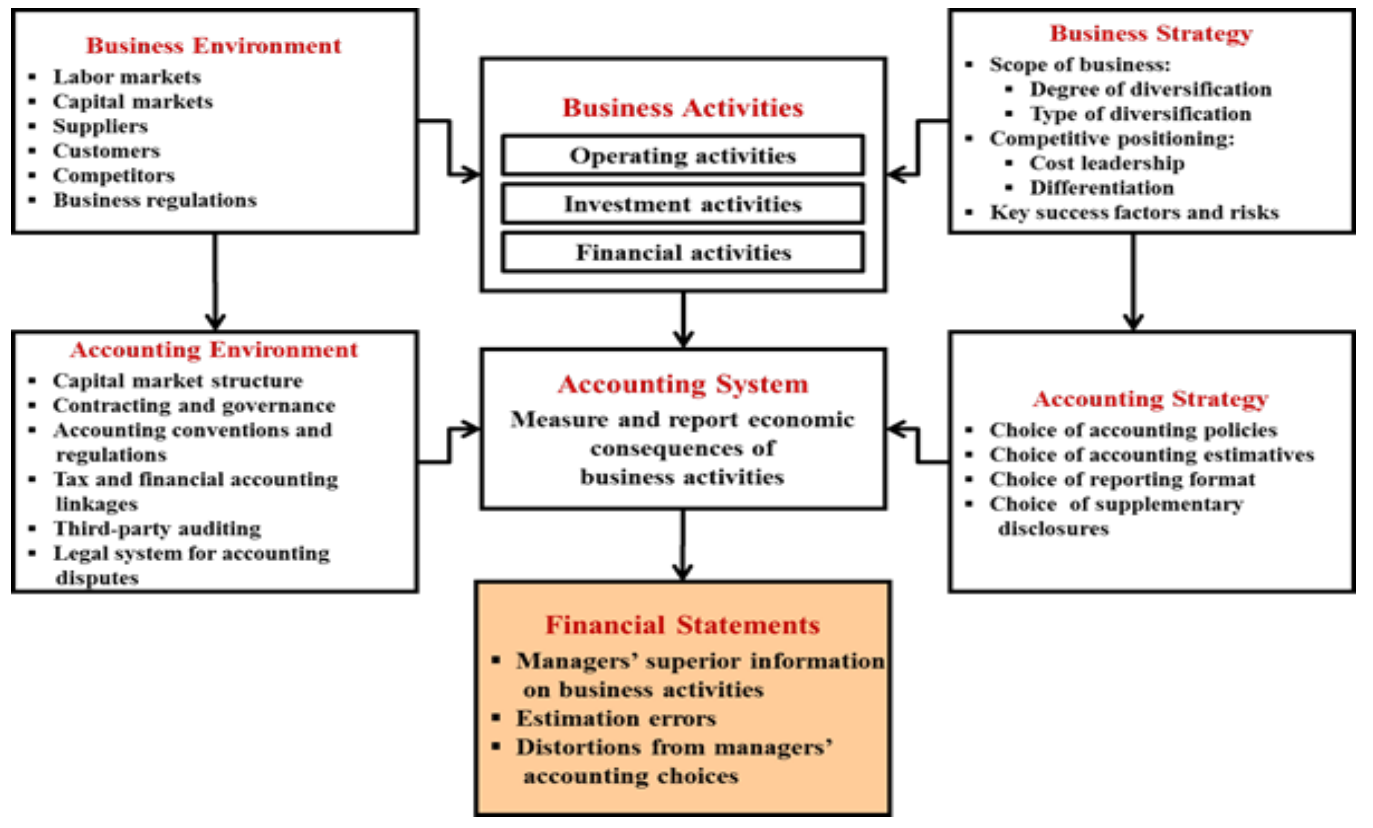


According to Palepu and Healy (2008, p. I-4), "the firm's accounting system provides a mechanism through which business activities are selected, measured, and aggregated into financial statement data". It is important to note that both the "business environment" in which companies' operate and the adopted "business strategy" influence companies' economic activities. The company's long-term vision (business strategy) orients investing and financing in the medium term and its operating activities (the short-term activities performed on a daily basis) through the company's performance in the business environment.

It is also important to note that this process requires considerable professional judgement, since countless choices regarding accounting policies and estimatives should be made, so that business activities could be processed by the accounting system and disclosed on accounting statements. It is therefore necessary for accounting professionals to act upon "Responsible Subjectivity" (ludícibus, 1998), which combines (i) the necessity of professional judgement and a certain amount of subjectivity with (ii) the necessity of appropriate moral education and social commitment.

One might ask, however: why is accounting capable of contributing to future cash flows projections? And what makes accounting useful? Actually, there is only one attribute responsible for this: the use of accruals, that are the necessary adjustments to applying the accrual principle. Therefore, "it is possible to argue that the accounting informational content rests on the accrual basis" (Lopes; Martins, 2007, p. 69).

Following Palepu and Healy (2008), Scott (2012) and Lopes and Martins (2007), it is the accruals that allow accounting to contribute to future cash flows projections. In other words, accounting would be useless without the accruals. Nevertheless, Lopes and Martins (2007) highlight that accruals introduce a major, crucial challenge to Accounting Theory: discretion. According to Lopes and Martins (2007, p. 72), "if accruals provide information on a company, it is natural for them to be totally discrete. This means that managers are free to use accruals to provide information to the market".

That is a fundamental issue for accounting, for the same thing that makes it useful can also hinder the earnings management, misrepresent the economic reality and compromise comparability. Therefore, Palepu and Healy (2008) point to four aspects that affect the accounting system quality: (1) accruals, by themselves; (2) accounting standards and conventions; (3) managers' reporting strategies; (4) third-party auditing.

Handling accruals is a complex task, because they are expectations of what present managing actions will have as future cash consequences. Moreover, it is a rather subjective task that draws heavily on a myriad of assumptions (Palepu; Healy, 2008). In this regard, accounting standards and conventions, as well as third-party auditors, may affect directly the accounting information quality. On the on hand, accounting standards and conventions (the conceptual structure, in IASB terms) may restrict the choices and orient and dictate accounting practices and procedures (regulation). On the other hand, third-party auditors may ensure that companies comply with accounting regulations and examine accounting statements quality and its correspondence to the companies' economic reality (certification). However, this perspective is subject to moral hazard. Hence, control mechanisms should be adopted, for instance, internal control and risk analysis systems.

\section{REVIEWING THE ACCOUNTING PROCESS: A FORETOLD CRISIS?}

Following this line of reasoning lead to an inevitable question: are accounting information actually relevant for the financial and capital market? From a conceptual standpoint, as argued above, the answer seems rather obvious: yes. In the real-world market, however, where all transactions take 
place and accounting statements are analyzed and interpreted, the answer to the same question is no simple or obvious - considering that other "competitor" information sources are also available for the financial and capital market.

In order to answer this practical question, it was necessary for the Accounting Theory to change. Then, the main concern had been to impose "the best move" when executing an accounting process (normative accounting theory), now the main concern was to "explain" and "predict" market reactions, the regulatory environment, etc. (positive accounting theory) (Watts; Zimmerman, 1986; Lopes; Martins, 2007). From this new perspective, researching efforts, since the seminal studies of Ball and Brown (1968) and Beaver (1968), have been channeled to explain, understand, correlate and predict the effects of accounting information being available to the financial and capital market, as well as to identify its causes and effects. It is important to note that, evidently, this change process has been carried out under the positivist/functionalist paradigm view of classical economic theory.

Different authors argue that accounting information is relevant to the financial and capital market, for example Ross (1983), Kothari (2001), Penman (2001) and Morricone et al (2009), mentioned in the introduction, Brown and Kenelly (1972), May (1971), Kiger (1972) and Morse (1981) apud Lopes and Martins (2007), as well as Ball and Brown (1968) and Beaver (1968), who we have just mentioned above, among many others. However, Lopes and Martins (2007, p. 79) argue that "a thorough literature review allows us to conclude that accounting information is relevant, but its explanatory power is low".

That leads to naturally question the accounting process efficiency. If accounting information is relevant, it means that the financial and capital market acknowledges it usefulness, as well as its ability to help predicting future cash flows. In contrast, if the explanatory power of accounting information is low, it means that the accounting process is not effective enough to capture the economic essence of business activities, which, in turn, decreases its usefulness. That leads to another question: why does the accounting process' efficiency have decreased?

Attempting to answer that could lead us to an answer both simple and complex: the world has changed, but the way the accounting process represented business transactions have not changed so much . Thus, the accounting process found itself not aligned with the new market practices, and was, therefore, obsolete, because it was no capable of capturing the economic essence of business operations appropriately. As a result, accounting statements have been far-off from companies' economic value.

It is important to emphasize, however, that accounting is a means for inquiring about companies' economic value, but it is not a means for inquiring about their market value. A company's market value is determined by the market itself. Nevertheless, if the market-assigned value to a company is very different than the one reported on the accounting statement, it means that something relevant (e.g. an asset or a liability) was not recognized or measured appropriately by accounting, but it was by the market. Moreover, the market priced this asset or liability somehow. Therefore, accounting should not aim for being as close to the companies' market value as possible; rather, those who make the accounting statements (managers, accountants and auditors) should do their utmost to ensure they exhibit the economic essence of business transactions, as illustrated by Figure 1.

This gap prompted the questioning of accounting measures of profit, return on equity, return on assets, among others. Thus, accounting information had been brought to question. Models such as Economic Value Added (EVA ${ }^{\oplus}$, Market Value Added (MVA ${ }^{\oplus}$ ), and Balanced Scorecard (BSC) have 
endeavored to expose the accounting measures' failures and to demonstrate how they "solved" these problems and why they were the most efficient models for evidencing the business reality.

In order to better understand this, it will be rather useful to bear in mind the process illustrated by Figure 1. The "business environment" where companies operated has changed. The market has changed, because people have changed, because the way people communicate has changed, because the way people evaluate and valuate things and goods (or services) has changed. The consumer behavior has changed. The production process has changed. In sum, all the aforementioned have changed because society was not the same and introduced new challenges to the accounting process. Hence, companies need to adapt their "business strategy" so that they could remain competitive in this new market - this "new economy".

Upton Jr. (2003, p. 473) presents the distinctive features of this new economy, typically found in the literature, namely: knowledge, capital knowledge, know-how, intellectual capital, internet, technology, information, intangible assets, knowledge sharing and new organizational forms, network effects and globalization. Lev (2001, p. 20) argues that in this new economy the importance of intangible assets results from two major forces confluence: (1) considerable changes in companies' structures; (2) information technology and scientific innovations far-reaching.

Companies' accounting systems were facing deep changes: on the one hand, changes in the "business environment", which affected the "accounting environment"; on the other hand, changes in the "business strategy", which affected the "accounting strategy" (see Figure 1). In the middle of all these changes and possibilities lies the accounting process, consolidated in an industrial society that is evolving into a high-tech and intangible society.

In this regard, Macintosh (2002, p.xi) argues that accounting professionals faced a"representational crisis" of unprecedented magnitude, and emphasizes that one of the first symptoms of this crisis was that the ration of accounting book value to stock market capitalization had fallen abruptly since the 1980s, while, over the same period, price-to-earnings ratios had tripled for the top 500 S\&P companies and quadrupled for those in NASDAQ index. "The problem was that the return on intangible assets was now outstripping returns on physical and financial assets" (Macintosh, 2002, p. xii). This leads to a new question: why has the accounting process failed in represent the companies' economic essence and, consequently, has been undervaluing their economic value reported on accounting statements?

It is not difficult to find that the accounting process that took place in the so-called Old Economy (practiced by the industrial society) was not appropriate for dealing with the new challenges of the New Economy (practiced by the new, high-tech, intangible society). According to Hand and Lev (2003), wealth and growth in modern economy are mostly driven by the intangible assets, such as patents, bioengineered drugs, brands, strategic alliances, customer lists, internet-based supply chain cost reduction; they are not driven by fixed asset anymore, such as machines and equipment, industrial plants, real state and vehicles - as in the old economy. Hand and Lev (2003) also stress that market leader positions, abnormal profits and competitive advantage (even if temporary) can be more effectively achieved by installing intangible assets.

It is important to note that accounting professionals did not stood still, watching passively this market change. We must acknowledge the research endeavor and all concrete actions, both by the academy and by accounting regulatory bodies, such as IASB and FASB, internationally, and IBRACON, CVM, CFC and, more recently, CPC, in Brazil. Moreover, remarkable progress was made in the recognition and measurement of assets like financial instruments, and intangible and fixed assets. 
In order to exemplify the progress in recognizing assets, especially in Code Law countries like Brazil, it is possible to mention the orientation which dictates that a good or right controlled by a company, through which can profit (future cash flows) and need to take risks, should be recognized as an asset. Until 2007 that was not allowed by Brazilian tax laws, for only goods and rights owned by the company that could be recognized as assets. That led to impressive distortions . For example, assets under leasing contracts could not be recognized as assets, even when they were the company's main responsible for revenue generation.

As for the progress made in measurements of assets, it is worth mentioning the major usage reduction of historical-cost as base value, and of input values as the only criterion for evaluating assets. International Financial Reporting Standards (IFRS) does not consider the cost as the main base value, since fair value is the prevailing concept. Cost is used for recognizing some assets (almost exclusively in the initial measurement), because the value paid for a good or right (its cost) generally represents its fair value. In a later measuring, however, specific criteria for each asset type should be followed; for example, Investment Properties should be valuated on release date based on its fair value.

Even though it has already been pointed above, it is important to highlight that, form an Accounting Theory standpoint, this is a major change. Because, following the IFRS, most assets should not be valuated as input values, but under output values, such as the net realizable value or future cash flow values, which depends on the type of asset. However, that does not mean that all problems were solved. The net realizable value is a relevant, up to date information and represents the value paid by the buyer/customer today, but it does not represent future estimate cash inflow.

Nevertheless, as stated above, endeavors have not succeed yet in allowing the accounting process to get closer again to most companies' economic reality in this new economy. That is a difficult task concerning companies rich in intangible assets, but not only them. As suggests Macintosh (2002, p. 134), intangible assets are today the main responsible for the revenue of all kinds of companies (not only the new-economy ones). In this regard, Hand and Lev (2003, p. 1) state that the importance of intangible assets has expanded, since they are not restricted to high-tech companies, but are crucial to every well-managed company.

Following Amir and Lev (1996), Lev and Sougiannis (1996), Lev and Zarowin (1999), Aboody and Lev (1998), Hand and Lev (2003), Lev et al (2005), abroad, and Lopes and Rezende (2005), Alencar and Dalmácio (2006) and Almeida et al (2009), in Brazil, accounting rules do not allow the complete recognition of intangible assets economic value; actually, most intangible assets are not even recognized as assets and but as expenses in the current period. Thus, Macintosh (2002) concludes that intangible assets are the main cause for the accounting representation crisis, since recognition, measurement and disclosure issues remain unresolved. He also exemplifies that: comparison between revenues and expenditures originating from intangible assets remains arbitrary and without theoretical support.

\section{INTANGIBLE ASSETS: BEYOND THE TRADITIONAL ACCOUNTING VIEW}

In this regard, both the importance of intangible assets and the complexity in its recognition, measurement and disclosure seem evident. One might ask, however: what is an intangible asset? Upton Jr (2003) argues that some terms used in the new economy became popular, such as capital knowledge, 
human capital and intellectual capital, but their meaning varies a great deal in the literature, rendering them useless when describing anything that we may consider as capital.

These terms have been sometimes used as synonym for intangible assets, sometimes used rather narrowly, referring to accruals or a specific intangible asset. This essay addresses intangible assets in its broader sense, whilst more specific cases are addressed as specific intangible assets, such as brands, patents, research and development, intellectual capital, strategic alliances, capital knowledge, labor force, copyrights, franchises, organizational culture, goodwill, etc.

It is, therefore, necessary to conceptualize "intangible asset", but, again, there is no universal agreement about it on the literature. Reilly and Schweihs (1998) argue that there are multiple definitions (regarding law, accounting and taxation), each with a specific purpose. Thus, this essay will point to some definitions, which proposition will help outline a broader concept.

Hendriksen and Van Breda (1999) refer to intangible assets as non-physical (absence of matter or physical substance) permanent assets, which value depends on future economic benefits granted by their ownership. These authors also state that intangible assets constitute one of the most complex areas of Accounting Theory, mostly because of its high uncertainty degree related to its values measurement and its lifespan estimation, that being more important than the physical substance.

Damodaran (2007) and Howard (2008) also affirm that intangible assets have no physical substance, and define them as assets that cannot be seen, felt or touched. In this regard, Scott (2012) conceptualize intangible assets as capital goods with no physical substance. Hand and Lev (2003, p. 1), in turn, define intangible assets as "rights to expected future benefits that have no physical or financial embodiment". Amaral $(2012, p, 140)$ conceptualize intangible assets in a broader way: "incorporeal/immaterial factors that contribute to goods and services generation, whereby their manager and/or owner expect present and future benefits"; and he also adds: "due to informational asymmetry or differences in perspectives and expectations, not every intangible asset can be identified immediately by all agents".

Accounting regulatory bodies (IASB, through IAS 38; CPC, through CPC 04) define intangible assets as a non-monetary identifiable asset with no physical substance. However, it is important to note that these regulatory bodies also ascribe a new characteristic, fundamental for accounting recognition: to be identifiable. From an accounting perspective, intangible assets has been defined by the absence of physical substance, but, in order to be recognized as an asset, they have to be identifiable. Hence, intangible assets have to be distinct, separable from other assets and have to comply with IFRS conceptual structure for assets, namely: they must be managed by the company as a result of a past investment, upon which it is expected for future economic benefits to flow into the company.

Reilly and Schweihs (1998, p. 5) add that the existence of any intangible asset depends on its association with a specific set of legal property rights. They also argue that the most typical characteristics or features necessary to qualify an intangible asset include: (a) it must be object to specific identification and recognizable description; (b) it must be object to legal existence and protection; (c) it must be subject to private property rights, that must be legally transferable; (d) it must have a tangible manifestation or proof of existence (such as a contract, a license, a disc, a customer list, a set of financial statements, etc.); (e) it must have been created or entered into force in an identifiable moment or as a result of an identifiable event; $(f)$ it must be subject to destruction or to cease its existence in an identifiable time or as a result of an identifiable event.

Scott (2012) claims that, due to some intangible assets' particular characteristics, such as brands, copyrights, licenses and franchises, they are generally accounted as the traditional fixed assets when 
purchased. Sometimes, even intangible assets developed internally are accounted as fixed assets. In such cases, intangible assets have been accounted by using the amortized cost method, due to its estimated lifespan. When purchased in a business combination, and it is possible to reliably determine their fair value, intangible assets must be recognized and measured by their fair value.

After meeting the recognition criteria, an intangible should be registered as an asset. However, in most cases it is difficult to reliably identify, separate and estimate an intangible asset cost and/or fair value. Following Hendriksen and Van Breda (1999) and Scott (2012), the cause is that intangible assets are generated internally, gradually, over time, and costs may be dilute over many years, rendering it difficult to associate with future net benefits.

Consequently, IAS 38 and CPC 04 require that most research and development costs, as well as other intangible assets generated internally, must not be recognized as assets, rather, they must be accounted under expenses. Nonetheless, Scott (2012) argues that it is important to be aware of the intangible assets' existence, even when they are not present in the Balance Sheets. Alternatively, due to its delayed recognition, intangible assets are demonstrated by Income Statements (Hendriksen; Van Breda, 1999; Palepu; Healy, 2008; Scott, 2012). In other words, since accounting based on incurred costs needs intangible assets to be perceived on sales and profits, Income Statements only contain the current "portion" of intangible assets' value.

Nevertheless, it is important to bear in mind that such accounting procedures make accounting statements depart form companies' economic reality and lead to undervalue their economic value, which contributes to the representation crisis suggested by Macintosh (2012). Thus, accounting professionals face a new question: should intangible assets be recognized in Accounting Statements when perceived or should their fair value be measured and reported in Balance Sheets?

Palepu and Healy (2008) and Scott (2012) argue that reporting the fair value of intangible assets may increase the usefulness of accounting information for decision-making; because they are capable of revealing the managers' information about future profit expectations, and managers' information are the best in revealing those profits' power. However, those same authors warn that reporting the fair value of intangible assets lead to serious reliability problems.

Thus, as demonstrated above, accounting professionals face again the discretion dilemma, even though discretion is essential for accruals to contain the information of accounting statements and for the accounting statements to contribute effectively to future cash flows projections again. Macintosh (2002) and Hand and Lev (2003) suggest that this dilemma must be confronted, so that accounting may restore its informative usefulness. Nevertheless, Macintosh (2002) warns that aligning the accounting procedures with this new reality requires that accounting professionals face this challenge in a different way - unlike than what has been traditionally done. Or, in Albert Einstein's words "we cannot solve our problems with the same thinking we used when we created them".

Therefore, it is necessary to think anew, beyond the traditional accounting. It is necessary to be set free from at least part of the current accounting paradigm that has become strongly positivist and influenced by classical economic theories. It is worth noting that, in principle, the positivist bias may seem contradictory, since accounting is an applied social science whose study object - wealth - is generated through complex social relations involving a flow of intangible and tangible operations.

In view of this, Cardao-Pito (2012) offers an alternative approach with his "intangible flow theory". However, it is important first to expand the understanding of the meaning of "intangible", not limiting oneself to current accounting criterion of recognition, in order to figure out how the accounting process 
may incorporate it. Cardao-Pito (2012) first addresses this discussion asserting "the word intangible means not tangible" and highlights the Merriam-Webster definition of the word: (i) capable of being perceived especially by the sense of touch; (ii) capable of being precisely identified or realized by the mind; and (iii) capable of being appraised at an actual or approximate value. He defines that intangible assets are identifiable and their value can be approximated, even if sometimes it will be a difficult or even impossible task.

Nonetheless, Cardao-Pito (2012) also defines that accounting and financial methods used by the market are not adequate for valuing intangible assets, because, since those methods are influenced by classical economic theories, which are purely positivists by nature, they are not able to capture the complexity of market relations (social relations) that are permeated by what he calls "intangible flow". It is important to bear in mind that the last two characteristics of tangible presented above are taken as premises for the accounting recognition of intangibles as assets, which suggests a concept misalignment and leads to a question: how can intangible items have the same characteristics of tangible items? Therefore, some intangible items are expected to not be recognized as assets, because only intangible assets that, by nature, are more similar to tangible would be recognized as assets. Consequently, that suggests the existence of an intangibility continuum, from most to least tangible items.

Therefore, it is possible to advocate the existence of an intangibility continuum. Bateson (1979) apud Cardao-Pito (2012) discuss the different approaches to intangibility and identifies two types: (i) physical intangibility, and (ii) mental intangibility. According to the first approach, a product could be considered intangible if it is not palpable or cannot be touched - but, as Flipo (1988) adverts, immateriality does not mean imperceptibility. And according to the second approach, a product could be considered intangible when it cannot be grasped mentally.

Shostack (1977) proposes a product scale based on their intangibility. Thus, one pole features the most tangible items (e.g. computers and clothing) and the other pole the most intangible (e.g. consulting and training services), and along the scale we find goods/services that have both tangible and intangible characteristics. At this point, it is important to define physical goods and services . Following Rathmel (1966, p. 33), services are "acts, deeds, performances, or efforts", and physical goods are "articles, devices, materials, objects, or things".

The scale proposed by Shostack (1977) aligns with Rathmel (1966), for the latter concludes that very few products are purely services or physical goods. There is a permanent relation between them, and some tangible elements depend on intangible elements. Cardao-Pito (2012) calls that the "intangible flow", and it is processed socially through dynamic and complex economic relations. Thus, as stated above, the accounting and financial view is not able to capture all the necessary aspects through their positivist "lenses", which leads to undervaluing the intangible assets.

\section{CHALLENGES FOR THE RECOGNITION AND MEASUREMENT OF INTANGIBLE ASSETS}

As demonstrated in the previous sections, the biggest challenge for recognizing and measuring intangible assets may be their high uncertainty degree: uncertainty about their future potential of cash generation, uncertainty about the moment when the cash generation starts and until when should it exist, uncertainty about their lifespan estimations, uncertainty about growth rates and profit margins, etc. 
Handling uncertainty means handling risk, estimations, judgement, subjectivity and discretion. Handling judgement and subjectivity requires unblemished ethical and moral conduct, as well as high education level. That leads to the challenge of justifying decisions properly, which allows the verification of their causes.

Subjectivity permeates most existing methods for evaluating intangible assets, so there is no consensus about the best evaluating methods. That has hindered the creation of a widely accepted method for evaluating intangible assets, which contributes to their misrecognition, since, from an accounting standpoint, existing methods are not sufficiently reliable (objective) for their measurement. If, from the accounting standpoint, those methods are not sufficiently reliable, the financial and capital market in turn makes considerable use of them in purchase and sale transactions of specific intangibles (such as brands, softwares, copyrights, client portfolios, etc.), especially in merges and acquisitions processes.

Considering the intangibility degree discussed above, consisting of a cline along which intangible assets lie from more tangible to more intangible, it does not seem reasonable for only one method to be adequate and widely accepted for evaluating every intangible asset. Quite the opposite, it seems reasonable for different methods to be more or less adequate to each type of intangible asset under valuation. In this regard, Damodaran (2007) groups intangible assets into three different categories, and, besides defining these categories, suggests the most adequate valuation methods, presented in Table 1.

Tabela 1: Estatística Descritiva

\begin{tabular}{|c|c|c|}
\hline Category & Definition & Valuation method \\
\hline $\begin{array}{l}\text { Independent and chas flow } \\
\text { generating intangible assets }\end{array}$ & $\begin{array}{l}\text { The most simple to valuate, because they ge- } \\
\text { nerate cash flows by themselves and can be } \\
\text { identified. Examples: trademarks, copyrights, } \\
\text { licenses and franchises. }\end{array}$ & $\begin{array}{l}\text { The discounted cash flow is the most } \\
\text { recommended method for this valua- } \\
\text { tion. }\end{array}$ \\
\hline $\begin{array}{l}\text { Firm-wide cash flow gene- } \\
\text { rating intangible assets }\end{array}$ & $\begin{array}{l}\text { Tend to be difficult to isolate and valuate, be- } \\
\text { cause they do not generate cash flow by them- } \\
\text { selves, but they allow a company to charge } \\
\text { higher prices and generate more cash flow. } \\
\text { Examples: brand, intellectual capital and goo- } \\
\text { dwill. }\end{array}$ & $\begin{array}{l}\text { Both the discounted cash flow and } \\
\text { the multiples valuation are the most } \\
\text { recommended methods for this } \\
\text { valuation. }\end{array}$ \\
\hline $\begin{array}{l}\text { Intangible assets with po- } \\
\text { tential future cash flows }\end{array}$ & $\begin{array}{l}\text { The most difficult to valuate, because they do } \\
\text { not generate cash flow in the present, but they } \\
\text { can in the future. Examples: undeveloped pa- } \\
\text { tents and natural resources. }\end{array}$ & $\begin{array}{l}\text { Since they have "options" as characte- } \\
\text { ristics, real options valuation models } \\
\text { are the most recommended for this } \\
\text { valuation. }\end{array}$ \\
\hline
\end{tabular}

Source: Damodaran (2007).

Subjectivity may be main cause for the excess of conservatism in accounting regulations, since objectivity has always been taken for granted both for the professionally and to the Generally Accepted Accounting Principles - today replaced by the Conceptual Structures. Objectivity is usually associated with confidence, neutrality, exemption and impartiality, the latter being always sought in academic circles and preconized by the Regulamento do Imposto de Renda, since it can be verified.

The dogmatic view of objectivity in the Accounting Sciences may also be explained through the positivist bias, present in its predominant philosophical base, through the accounting scientism pre- 
conized by Watts and Zimmerman (1986) and that are present in accounting up to this date. Objectivity has always been (and still is) highly regarded, either through the Normative Theory bias, today found in most accounting regulations, especially IASB and FASB, or through the Positive Theory bias, widely observed in the literature: objectivity has always been associated with reliability.

\section{CLOSING REMARKS}

This essay aimed to discuss some relevant issues concerning the conceptual model present in accounting procedures used for identifying and measuring intangible assets. In the previous sections, we presented the reasons why those accounting procedures have been questioned and how they have proved inadequate for their intended purpose, conducting accounting to a representation crisis (Macintosh, 2002).

The empirical researches reported in this essay address these questions from a scientific standpoint, putting its conceptual and theoretical framework to the test; and the financial and capital Market address these questions from a practical and operational standpoint, putting its usefulness to the test. Both academy and market suggest that the philosophical and theoretical basis should undergo a major revision, since the led accounting to the present paradigm.

This essay tried not to argue in favor of subjectivity, as a magical instrument capable of solving all problems related to measurement in the current accounting model. On the contrary, this essay tried to discuss the conservatism excess, partly motivated by the objectivity dogmatism, which in turn is often seen as a magical instrument capable of eliminating all bias from Accounting Statement makers. At last, this essay also tried to demonstrate that, in order to work with intangible assets, the same rules, concepts and methods that are appropriate to work with tangible assets must not be used.

Therefore, to overcome this challenge it is necessary to identify the obstacles created by the strongly positivist accounting paradigm that hinder the identification, measurement and disclosure, especially related to intangible assets; and also to contribute, at least partly, to the construction of a new conceptual and theoretical basis that may support the accounting process to capture and represent companies' economic realty in a more appropriate way.

Nonetheless, one issue seems to be inevitable: the accounting professionals will have to face the challenge of subjectivity and discretion, feared by some, desired by others, but fundamental to everyone. Without subjectivity and discretion, accounting will remain far-off from the company's economical representation.

REFERENCES

Aboody, D., Lev, B. (1998). The value-relevance of intangibles: the case software capitalization. Journal of Accounting Research, 36, 161-191.

Akerlof, G. (1970). The Market for "lemons": quality uncertainty and the Market mechanism. The Quartely Journal of Econimics, 488-500.

Alencar, R. C., Dalmácio, F. Z. (2006). A Relevância da informação contábil no processo de avaliação de empresas da nova e velha economia: uma análise dos investimentos em ativos intangíveis e seus 
efeitos sobre value relevance do lucro e do patrimônio líquido. In: XXX ENCONTRO NACIONAL DA ANPAD, 2006, Salvador. Anais eletrônicos... Disponível em: <http://www.anpad.org.br/enanpad/2006/ dwn/enanpad2006-fica-3139.pdf>. Acesso em: 27 set. 2010.

Almeida, J. E. F. de, Bispo, J. de S. \& Fávero, L. P. L. (2009). The Value Relevance of the Information Content of Deferred Assets in Brazilian Public Companies: Does this Information Matter to the Market? In: Annual Congress of the European Accounting Association, 32th, 2009, Tampere (Finlândia). Anais... Tampere: EAA - European Accounting Association.

Amaral, H. F. (2012) Proposta teórico-empírica para identificação e avaliação de ativos intangíveis. Tese (Concurso para professor titular). Faculdade de Ciências Econômicas. Universidade Federal de Minas Gerais, UFMG.

Amir, E., Lev, B. (1996). Value-relevance of nonfinancial information: The wireless communications industry. Journal of Accounting and Economics, 22, 3-30.

Ball, R., Brown, P. (1968). An empirical evaluation of accounting income numbers. Journal of Accounting Research, 6, (autumn), 159-178.

Beaver, W. H. (1968). The information content of earnings announcements. Journal of Accounting Research, 6, 67-92.

Cardao-Pito, Tiago. (2012) Intangible flow theory. American Journal of Economics and Sociology. 71(2), 328-353.

Damodaran, A. (2007). Avaliação de empresas. 2a ed. Trad. Marcelo Arantes Alvim e Sonia Midori Yamamoto. São Paulo: Pearson. (Tradução de: Damodaran on valuation: security analysis for investment and corporate finance. 2 sd ed., 2007).

Fama, H. (1970, May). Efficient Capital Markets: A Review of Theory and Empirical Work. The Journal of Finance, 25(2), 383-417.

Flipo, J. (1988). On the Intangibility of Services. Service Industries Journal. 8(3), 286-293.

García-Ayuso, M. (2003). Factors explaning the inefficient valuation of intangibles. Accounting, Auditing \& Accountability Journal. 16(1), 57-69.

Hand, J. R. M., Lev, B. (2003) Intangible assets: Values, measures, and risks. New York, NY: Oxford University Press.

Hendriksen, E. S., Van Breda, M. F. (1999). Teoria da Contabilidade. Trad. Antonio Zoratto Sanvicente. São Paulo: Atlas. (Tradução de: Accouting theory, 5th ed., 1992). 
Howard, M. (2008). Accounting and business valuation methods. Oxford, UK: Elsevier.

ludícibus, S. (2010). Teoria da Contabilidade. (10nd ed.). São Paulo: Atlas.

ludícibus, S. (1998, Março e Abril). Conhecimento, Ciência, Metodologias Científicas e Contabilidade, Parte II. Kothari, S. P. (2001). Capital Markets Research in Accounting. Journal of Accounting and Economics. 31, 105-231.

Lev, B. (1989). On the usefulness of earnings and earnings research: lessons and directions from two decades of empirical research. Journal of Accounting Research. 27.

Lev, B. (2001). Intangibles: management, measurement and reporting. New York, NY: Brookings Institute Press.

Lev, B., Radhakrishnan S. (2003). The Measurement of Firm-Specific Organization Capital. NBER Working Paper Series, Massachusetts Avenue, Cambridge, March, Disponível em <http://www.nber.org/papers/ w9581>. Acesso em 30 set. 2010.

Lev, B., Sarath, B., Sougiannis, T. (2005) R\&D reporting biases and their consequences. Contemporary Accounting Research. 22, 977-1026.

Lev, B., Sougiannis, T. (1996). The capitalization, amortization and value-relevance of R\&D. Journal of Accounting and Economics. 21, 107-138.

Lev, B., Zarowin, P. (1999). The boundaries of financial reporting and how to extend them. Journal of Accounting Research. 37(2), 353-385.

Lopes, A. B., Martins, E. (2007). Teoria da contabilidade: uma nova abordagem. São Paulo: Atlas.

Lopes, A. B., Rezende, A. J. (2005). A Relevância da informação contábil no processo de avaliação de empresas da nova e velha economia: uma análise dos investimentos em ativos intangíveis e seus efeitos sobre value relevance do lucro e do patrimônio líquido. In: Congresso Brasileiro de Finanças, 5., 2005, São Paulo. Anais... São Paulo: SBFIN, 2005. 1 CD-ROM.

Macintosh, N. B. (2002). Accounting, accountants and accountability: poststructuralist positions. London: Routledge.

Martins, E. (1972). Contribuição à avaliação do ativo intangível. 109p. Tese (Doutorado em Controladoria e Contabilidade). Universidade de São Paulo.

Morricone, S., Oriani, R. \& Sobrero, M. (2009, June 1). The Value Relevance of Intangible Assets and the Mandatory Adoption of IFRS. Disponível em <http://ssrn.com/paper=1600725>. Acesso em 12 set. 2010. 
Palepu, K. G., Healy, P. M. (2008). Business analysis \& valuation: using financial statements. 4th ed., South-Western, Cengage Learning.

Penman, S. (2001). Financial statement analysis and equity valuation. Boston: McGraw-Hill.

Rathmel, J. (1966). What is Meant by Services. Journal of Marketing. 30(5), 32-36.

Reilly, R. F., Schweihs, R. P. (1998). Valuing intangible assets. New York, NY: McGraw-Hill.

Scott, W. R. (2012). Financial Accounting Theory. (6nd ed.) Toronto: Pearson Prentice Hall.

Shostack, G. (1977). Breaking Free from Product Marketing. Journal of Marketing. 41(2), 73-80.

Upton Jr, W. S. (2003). Challenges from the new economy for business and financial reporting. IN: Hand, J. R. M.; Lev, B. Intangible assets: Values, measures, and risks. New York, NY: Oxford University Press.

Watts, R. L., Zimmerman, J. L. (1986). Positive accounting theory. New Jersey: Prentice-Hall.

Wells, M. C. (1976). A revolution in accounting thought? The Accounting Review, 11(3).

\footnotetext{
I - IASB meeting, Agenda Proposal - Agenda Paper 5A, December 12, 2007.

II - Not to mention Hendriksen e Van Breda (1999, p. 83): "[...] in the perfect market typically depicted on economics textbooks there would be no place for accounting. It is necessary to reject those hypothesis, so that accountants have a raison d'être."

III - Notably, Accounting is not the only market source of information, as other agents also contribute to reduce the informational asymmetry, such as the press, the company, etc.

IV - For a comprehensive understanding on the sociological paradigms, see BURREL, G.; MORGAN, G. Sociological paradigms and organizational analysis: elements of the sociology of corporate life. Burlington, Ashgate Publishing Company, 2008. To understand these paradigms according to the Accounting Sciences view, see RYAN, B.; SCAPENS, R. W.; THEOBOLD, M. Research Method and Methodology in Finance and Accounting. 2 ed. London: Thomson, 2002.

V - For a comprehensive and contextualized view on the accounting research and activity over time, see HOPWOOD, A. G. Whither accounting research? The Accounting Review. Vol. 82, N. 5, 2007.

$\mathrm{VI}$ - "Accounting-financial information has a predictive value, if used as input data by users in processes to predict future results. Accounting-financial information does not need to be a prediction or projection itself in order to have predictive value. Accounting-financial information containing predictive value is used by users when making their own predictions" (Pronunciamento Conceitual Básico, QC8).

VII - As they were not recognized as "assets", these values were recognized as "expenses", distorting both the Balance Sheet and the Income Statement. For example, consider a certain number of trucks of a transport company under leasing contract. As they cannot be considered that company's property, Law 6099/1974 determined (and still determines, fiscally speaking) that payments should be accounted under "expenses" (art. 11), whilst only the paid Guaranteed Residual Value - GRV - should be recognized as "asset" (art. 15).

VIII - The main criticism made by the financial and capital market to accounting referred to the usage of historical cost as base value, because, over time, this measure weakened, leading to undervaluing the assets' market value. Wells (1976) argues that this was the first omen of the representation crisis that Macintosh (2002) credited to the intangible assets as the main cause.

IX - The main criticism made by the financial and capital market to accounting referred to the usage of historical cost as base value, because, over time, this measure
} 
weakened, leading to undervaluing the assets' market value. Wells (1976) argues that this was the first omen of the representation crisis that Macintosh (2002) credited to the intangible assets as the main cause.

X - IAS 38 and CPC 04 determine that research expenditures must be recognized as expenses, whilst development expenditures may be recognized as assets, if specific and rigorous criteria are met - on the contrary, they also must be recognized as expenses.

XI - Hendriksen and Van Breda (1999, p. 388) argue that "intangible assets are created in spending cash (or equivalent) in services".

XII - One of the most used methods by the financial and capital market is the Discounted Cash Flow method, which serves as a base to other methods, such as MEEM (Multiperiod Excess Earnings Method) and RFRM (Relief-from-Royalties Method). Both are widely used for evaluating intangible assets such as trademarks and patents. It is also worth mentioning the Replacement cost method, the Replication cost method and the Multiples method. XIII - See note xii again.

XIV - For a better examination of this role reversal between regulators and researchers, see MACVE, R. Trade places: a UK (and IFRS) Comment. Accounting, Economics and Law, Vol. 4, N. 1, 2014 